\title{
Forms of capital and modes of closure in upper class reproduction
}

Magne Paalgard Flemmen*, Maren Toft*, Patrick Lie Andersen ${ }^{a}$, Marianne Nordli Hansen*, Jørn Ljunggren ${ }^{\mathrm{b}}$

* Department of sociology and human geography, University of Oslo

1. ${ }^{a}$ NOVA, Centre for Welfare and Labour Research, Oslo and Akershus University College of Applied Sciences, Oslo, Norway

b Institute for social research

Corresponding author: Magne Paalgard Flemmen, Department of sociology and human geography, University of Oslo. P.O box 1096 Blindern. 0317 OSLO. Norway.

magne.flemmen@sosgeo.uio.no 


\begin{abstract}
:
We investigate the recruitment into the upper class, analysing the impact of different forms of capital and modes of closure. Unlike many Bourdieu-influenced approaches to class, we systematically investigate divisions by composition of capital: the relative weight of economic to cultural capital. We find capital-specific barriers to mobility: Access to the upper classes is not only differentiated by one's parents' volume of capital or the general class hierarchy, but also by the relative weight of cultural to economic capital. Drawing on theories of social closure, we further investigate the role of two distinct modes of closure - credentialism and private property. The degree of closure differs significantly between subfractions of the upper class, based on the degree to which they refer to positions involving specific credential requirements. Our findings underline the importance of capital composition, but also that closure operates by neither credentials nor property alone.
\end{abstract}

Keywords: class, closure, credentials, cultural capital, economic capital, education, elites, property, social mobility 
With the staggering increase in inequalities of recent years (Atkinson and Morelli 2014), the question of elites and upper classes is back on the agenda. The richest have increased their overall share of both income and wealth (see especially Piketty 2014). But who are the top strata and what is the nature of their social trajectories? Are they characterized by openness of access, or are they distinctively self-recruiting? These elites long appeared to be forgotten by social science (Savage and Williams 2008). Most strikingly, they rarely figure in mainstream approaches in class analysis, such as the now official measures of class, which only recognize a fairly broad 'salariat' as its category at the top (Rose and Harrison 2010, Rose and Pevalin 2003). The recent Great British Class Survey (GBCS) promised to bring the elites back in (Savage 2015), but its contribution has been contested and its status unclear owing to conceptual and methodical difficulties (see the June 2014 special section in Sociology and the May 2015 special issue of Sociological Review). In the present paper, we push this line of research further by analysing how inherited economic and cultural capital are shaping recruitment to upper class fractions, and how these intersect with educational credentialization and private property as two distinct modes of closure (Parkin 1979, Murphy 1988).

We see class divisions as manifested in the distribution of forms of capital (Savage, Warde, and Devine 2005). While it is widely recognized that economic, cultural and social resources are of great significance for understanding how class 'works' (Goldthorpe, Llewellyn, and Payne 1987:99, Khan 2012), it is with Bourdieu's perspective that they come to be seen as the most 'determinant property' of social class (Bourdieu 1984:106, see the discussion in Flemmen 2013). But unlike recent attempts at applying Bourdieu's ideas in class analysis, like the GBCS, we operationalize the class structure as two-dimensional, shaped by both the total amount of capital, but also the composition of this capital - the relative weight of economic to cultural capital (see Flemmen et al. forthcoming). We therefore distinguish four main hierarchical levels of the class structure - working class, lower middle class, upper middle class 
and upper class. We then differentiate the upper and middle groups into fractions by the type of capital, so that each is split into a cultural-capital fraction, an economic-capital fraction and a fraction with a balanced mix.

While most approaches to social stratification emphasize the significance of education, class analysis stresses the role of private property (Flemmen 2013): Marxians see class as anchored in relations of production (Wright 2005), whereas Weberians see the divide between the propertied and the property-less as the basic fault line in the class structure (Breen 2005). But education or property should not be an either/or choice, so we move beyond this dichotomy by drawing on theories of social closure: 'In modern capitalist society the two main exclusionary devices by which the bourgeoisie constructs and maintains itself as a class are, first, those surrounding the institutions of private property; and, second, academic or professional qualifications and credentials' (Parkin 1979:47-8). While the upper class as such might rely on both, its different fractions might rely on them to different degrees and in different combinations. To explore this, we distinguish between subfractions by their degree of credentialization - the extent to which access to the relevant positions is regulated by specific educational credentials - and whether access is regulated without such educational requirements, giving more leeway to the role of property through inheritance or other forms of intergenerational advantage. We use Norwegian administrative register data with comprehensive information on the entire population. Upper class positions are measured in the period 2003-2012 for individuals born 1955-1964 (n=609,499).

\section{Upper classes and social closure}

While class and stratification is a staple of contemporary sociology, there are too few studies of recruitment into the upper class. Indeed, the upper class - and in particular the propertyowning capitalists - has virtually vanished from most approaches to class structure. This is 
striking, given the centrality of the property dimension to both Marx (1976) and Weber (1978:926-32), who continue to serve as inspiration for contemporary accounts of class. In Goldthorpe's approach, now the basis of the official measure of class in the UK and the EU (Rose and Harrison 2010, Rose and Pevalin 2003), proprietors are lumped in with the broad upper middle class (Goldthorpe 1982, Erikson and Goldthorpe 1993). Erikson and Goldthorpe argue that large-scale proprietors today are organisations and corporations, rather than individuals, and individual capitalists have become so few that they are obsolete in surveybased analyses (Erikson and Goldthorpe 1993). But even if large-scale proprietors in contemporary societies tend to be organisations and corporations, these are still owned by individuals, so that a tiny part of the population enjoys superior life chances flowing from property ownership.

This group, then, cannot be analysed with representative surveys of usual size. Using population data lets us bypass this issue. Our understanding of the upper class is founded in what has been called a Capitals, Assets and Resources approach (see Savage, Warde and Devine 2005) in which multiple sections of the top segments of the class structure are recognized. In Bourdieu's rendition, social class divisions are understood in terms of the differential endowment of economic and cultural capital (Bourdieu 1984, 1986). Capital refers to any kind of competence or possession that is in short supply, unequally distributed and which is valued in some 'market' or social field, so that it may come to constitute an advantage for its holder. Economic capital refers to money, wealth or 'the indirect mastery ... of financial resources' (Bourdieu 2005: 194). Cultural capital refers to cultural competences, either in the embodied sense of mastery of valued lifestyles or in the institutionalized sense of educational credentials (Bourdieu 1986). The latter becomes a capital largely through its value in labour markets, whereas the former becomes an asset through the positive or negative evaluation it is subject to, not least within the school system (Andersen and Hansen 2011). 
Unlike much work in class analysis, we build on Bourdieu's recognition that these forms of capital might not add up one-dimensionally. Recognizing the different institutional bases of power, we operationalize Bourdieu's concept of a capital composition: within the same hierarchical level of the class structure, actors are differentiated according to the relative weight of cultural to economic capital in their overall holdings. Thus, the upper class is comprised of the most powerful actors from diverse fields - business, politics, academia, arts, etc. - and in practice measured as the actors richest in economic and cultural capital.

The theory of social closure was developed by Parkin (1979), drawing on Weber (1978: 43ff, 302ff, 336ff) to account for 'how collectives seek to maximize rewards by restricting access to resources and opportunities to a limited circle of eligibles' (Parkin 1979:44). Parkin maintained that the modern bourgeoisie relies on two distinct modes of social closure: private property and the educational system. Private property restricts access to the means of production, and in a more general sense confers market privileges through money, while credential requirements limit access to key positions in the social division of labour. Parkin placed a particular focus on how the different modes of closure were implicated in the social reproduction of the upper class. He diagnosed a 'permanent tension within this class resulting from the need to legitimate itself by preserving openness of access, and the desire to reproduce itself socially by resort to closure on the basis of descent' (Parkin 1979:47).

Some authors have argued that contemporary capitalism has undergone a shift from the family-based mode of class reproduction to a school-mediated form: the rise of impersonal property - join stock enterprises, institutional shareholdings, etc. - is seen as giving rise to a more prominent role to credentials and cultural resources in upper class reproduction (Bourdieu 1996, Scott 1997:292-310). But the different fractions of the upper classes might rely on these modes of closure to different extents and in different ways (see Flemmen 2012). However, the extent of credential closure, or the extent of closure by direct inheritance of property and more 
indirect in terms of economic advantages, could vary depending on the precise upper class positions in question.

\section{Elites in the Norwegian class structure}

While systematic studies of upper-class recruitment are few and far between, there are some studies of recruitment to different upper class positions. Earlier research found the Norwegian business elite, as well as the economic upper class more generally, to be disproportionally recruited from the upper class (Flemmen 2009, Gulbrandsen et al. 2002, Mastekaasa 2004). Moreover, there is some evidence suggesting increased social closure: 'having parents from the top echelons of wealth has, over time, become more important for reaching the highest levels of wealth' oneself (Hansen 2014:477).

Class-based recruitment appears persistent in other segments of the top strata of society as well. Within the upper class fraction with a balanced mix of economic and cultural capital the professions, politicians and NGO-leaders - evidence shows an overrepresentation of privileged social origins among politicians (Norris and Lovenduski 1995, Higley, Field, and Grøholt 1976, Klausen 2002, Andersen 2014); administrative elites (Hartmann 2010, Mastekaasa 2004, Page and Wright 1999); as well as lawyers and physicians (Hansen 2001, 2005, Strømme and Hansen, 2017). However, in many western societies, political elites have been found to be more accessible and egalitarian than administrative elites (Aberbach, Putnam, and Rockman 1981).

The cultural fraction of the upper class is much less studied, and indeed, not often recognized as a distinct class fraction (but see Ljunggren 2015, 2016). The Norwegian cultural upper class has been found to be strongly marked by self-recruitment and characterized by underrepresentation of lower-class progeny (Ljunggren 2010). Indeed, the cultural upper class 
is found to be slightly more self-recruiting than the economic or the balanced fraction. Moreover, the probability of experiencing downward mobility is lowest among those with parents rich in cultural capital, compared to those with rich in economic capital (Hjellbrekke and Korsnes 2010).

These studies unveil class-based reproduction that extends beyond the economic sphere. However, a systematic and integrated mapping of recruitment patterns into the top segments of the class structure has yet to surface. Moreover, there is almost no research on the different modes of closure facilitating reproduction in different segments of the upper class. The present study aims to make good on these shortcomings, providing the first analyses to allow direct comparison of the degree of closure of the different upper class fractions. We also provide the first attempt at illuminating the differences in intergenerational reproduction associated with different modes of closure.

The foregoing leads to the following expectations. First, we expect some degree of classfraction reproduction, so that the highest odds or probabilities of obtaining a position in an upper class fraction should pertain to originating in the same class fraction. Second, we expect that, for those not born into the upper class, the chances of joining the upper class should increase with parents' volume of capital. Children of the lower middle class should have higher chances than children of the working class; children of the upper middle class should have higher chances than children of the lower middle class, etc. Third, we expect horizontal differences: differentiation of chances by the composition of capital, so that it would be more probable for someone from the cultural fraction of the lower middle class to enter the cultural fraction of the upper class than it would be for someone originating the economic fraction of the lower middle class to do the same. Fourth, we expect varying degrees of closure operationalized in terms of the effect of parental class - by credentialization, i.e., by the extent to which access to positions depend on formal educational requirements. 
Theories of credentialism foster expectations of stronger intergenerational closure in groups with strong credentialization. However, capitalist market economies entail a generalised value of property in general and money in particular, so that economic resources should also prove influential within subfractions with low credentialization. That would suggest social closure also in these groups. Parental resources, such as wealth, might itself constitute what has been referred to as a 'cushion' or 'insurance', which can facilitate the undertaking of risky ventures - or pursuing careers with unclear and/or uncertain prospects. It has for instance, been found that individuals who receive an inheritance are more likely to set up a business (Blanchflower and Oswald 1998), and parental wealth affects mobility chances more generally (Pfeffer and Hällsten 2012). By the same token, both access to, and success within, artistic occupations are highly affected by individuals' economic security (Friedman, O'Brien, and Laurison 2016, Ljunggren 2016). Thus, we hypothesize that even groups with low credentialization might exhibit a considerable degree of closure owing to the effects of private property. This could be the case for both self-employed, proprietors and rentiers (SPR); politicians as well as artists. To pursue a career in any of these subfractions may be seen as risky ventures where success requires long-term investments and having the possibility to, at least temporarily get by on a modest personal income. We expect those with less capital in the family to pursue these kinds of careers less often.

\section{Data and methods}

Our research design involves two crucial steps. First, we conceptualize social class divisions in terms of both volume and composition of capital for respondents and their parents. This lets us assess the degree of intergenerational self-recruitment in different classes and fractions. Second, we subdivide upper class fractions into subfractions based on their degree of credentialization. Within each fraction, we distinguish between sets of positions with clear and consistent 
credential requirements (professions, academics, and, arguably to a lesser extent, business professionals) from those with no such requirements (artists, politicians, selfemployed/proprietors/rentiers) - and a middle category for positions in which credentials are sometimes or often required for access (cultural directors, top bureaucrats, chief executives). This lets us assess the effect of social class origin on recruitment into these nine subfractions, so that we can compare the degree of closure between groups with differing regulations of access.

For this, we exploit Norwegian administrative register data that provide information on the entire Norwegian population born in 1955 onwards. These data comprise official registers on tax, employment and education, and ensures reliable information on income, occupation, and education. The authorities gather this data routinely for taxation purposes, as well as demographic surveying and official statistics, and they are administered by Statistics Norway. We can also link individuals to their parents, so that class origins can be determined. This data is unique in that it allows us to study very exclusive social groups which would only be represented by a handful of individuals in ordinary representative surveys. ${ }^{1}$

We use a novel operationalization of class inspired by the work of Bourdieu. The Oslo Register Data Class Scheme distinguishes classes and class fractions in two dimensions. ${ }^{2}$ It has first, a hierarchical dimension of the total amount of capital: it differentiates the highest from the lowest classes. In this hierarchy, class positions reflect the total volume of cultural and economic capital. We thereby identify four main classes: the upper, the upper-middle, the lower middle and the working class - as well as one category for those employed in the primary sector and one category for people whose livelihoods depend on welfare transferences. But cross-

\footnotetext{
${ }^{1}$ Migrants with missing information on either parental class (immigration) or adult class (emigration) are naturally omitted from the analyses. However, this applies to only about 1 per cent of the upper class. Excluding migrants from the analysis makes almost no difference. Results can be obtained upon request.

${ }^{2}$ Syntax for the construction of the class scheme can be obtained from the authors.
} 
cutting this is the second dimension of capital composition. We differentiate the three highest classes into cultural and economic fractions, as well as balanced fractions, conceptualised as having roughly similar amounts of economic and cultural capital.

The scheme is operationalized by classifying occupational titles, but is supplemented with information of income from the tax registers. We use the overall level of income to distinguish between levels in the economic fractions: the upper, the upper middle and the lower middle economic class fractions are distinguished by their relative income - as a proxy for their volume of economic capital. Second, we use information on capital gains and income from selfemployment to identify rentiers or capitalists among respondents without occupational codes and place these in one of the economic class fractions, depending on their level of income. Third, we use information on welfare transferences to identify those whose level of such transferences exceeds what they earn from other sources, placing them in the category for welfare transference dependants. Fourth, we assign those whose income derives mostly from farming, fisheries and forestry to the category 'primary sector'. The resultant scheme is shown in Figure 1.

The outcome variables in the subsequent analyses concern the likelihood of recruitment into the Norwegian upper class fractions (Figure 1) and their internal subfractions. We analyse the complete 1955-1964 cohorts and measure these cohorts' class position at an age where they are believed to be close to the apex of their careers, that is: at age $48,{ }^{3}$ i.e. in years $2003-2012$. The first outcome variable distinguishes between the three upper class fractions (cultural, balanced and economic), with one category for all other class positions in the ORDC scheme.

The second outcome variable concerns the divisions by credentialization. We have split each class fraction into three subfractions - with high, medium or low/no credentialization.

\footnotetext{
${ }^{3}$ If missing, class position at age 47 or 49 is reported.
} 
With this we aim to get at the degree to which access to the relevant class positions is regulated by credentials. These subdivisions are illustrated in Figure 2 . These classifications are based on occupational sorting and the final outcome variable includes a category for all other class positions in the ORDC scheme in addition to the 9 internal divisions within the upper class fractions. Multinomial logistic regression models are utilized as both outcome variables include multiple categories. ${ }^{4}$

Parental class position is also measured with the ORDC scheme. ${ }^{5}$ For each vertical level (working class, lower middle class, upper middle class, and upper class) we base the classification of the parent with the highest level. If both parents have an equal level, but different fraction, parental class is randomly chosen. ${ }^{6}$ If information of either parent is missing the other determines parental origin. Parental class is measured by using the census data from 1980, when these cohorts were between 16-25 years of age. Parental class in 1970 is reported if class origin is missing in 1980. Because class mobility may be different for men and women, our model includes an interaction term between class origin and gender. As each cohort is measured at age 48 - and therefore at different time periods - dummy variables for each year are also included. ${ }^{7}$ Descriptive statistics for all variables in the analyses are provided in Table 1.

\section{Results}

Table 2 shows coefficients (logit) estimating the association between parental class and the likelihood of obtaining a position in any of the three upper class fractions versus any other class

\footnotetext{
${ }^{4}$ Despite the rarity of events, the results are found to be robust when utilising penalized log likelihood (Firth) models.

${ }^{5}$ However, it is not possible to construct a "Welfare Transference"-category for 1970 and 1980

${ }^{6}$ This is of minor importance; about 8 per cent of the parents were on the same hierarchical class level but in different fractions.

${ }^{7}$ Yearly interaction terms revealed fairly stable associations and thus small changes in the time period of 20032012.
} 
position. ${ }^{8}$ Social origin in the unskilled working class is the reference category for the independent variable. Table 2 reveals clear tendencies of closure within the top fractions of the Norwegian social space. The largest differences follow the volume of capital, meaning that the biggest skew in upper class recruitment relates to the general class hierarchy. The likelihood of entering the upper class increases with parents' total volume of capital. The largest coefficients are systematically related to parental origins from the upper class followed by the upper middle class, the lower middle class, etc.

However, upper class recruitment is not only differentiated by parents' amount of capital. Table 2 reveals that the secondary principle of differentiation by the composition of capital is clearly effective, but of secondary importance. This means that, for recruitment into the economic fractions of the upper class, there is a relative advantage in originating in economic capital-rich fractions - i.e., the economic upper class or the economic upper-middle class -when we compare fractions on the same hierarchical level. The same logic applies to recruitment into the cultural upper class. Here chances increase with the preponderance of cultural capital in parents' overall capital endowments: there are higher chances for those originating in the cultural upper, upper-middle or lower-middle class. This relationship is evident for both men and women as visualised in Figure 3. The cultural upper class seems to be the most restricted group.

In other words, the strength of the associations predicts a likelihood of following the fractional footsteps of one's parents; for each upper class outcome the logit coefficients are larger if mirroring the capital composition of one's parents. The odds ratios may serve to ease the interpretation of these relationships. For instance, in comparison to men of unskilled working class origins, the odds of entering the cultural upper class are 19 times higher for those with parents from the cultural upper class. The odds are multiplied by 8 for access into the

\footnotetext{
${ }^{8}$ Our results are robust for differences in fertility. Results can be obtained upon request.
} 
balanced upper class fraction when having parents from the balanced upper class fraction, while multiplied by 14 for economic upper class reproduction. Hence, capital-specific mobility closure is prevalent. This tendency is sometimes significantly more pronounced for women than men. Indeed, social class origins seem to have a bigger impact on women's upper classrecruitment, as is suggested by previous research (see Flemmen 2009, Toft and Flemmen forthcoming). For instance, the relative odds for women's access into the economic upper class increase by a factor of 21 when originating in the economic upper class - significantly more than their male peers.

Further, such capital-specific mobility patterns are also evident among the progeny of the upper middle class; these associations are systematically higher for access into upper class fractions that match the capital profile of parental upper middle class origins. This is especially evident in the cultural fraction, where we also find the highest level of capital-specific closure.

Table 3 displays the results for internal, subfraction divisions according to the degree of credentialization within each of the upper class fractions. Table 3 shows that patterns of capitalspecific mobility closure are also highly visible when introducing these internal divisions. One field does, however, deviate from this pattern. Within the balanced fraction, positions within politics or the NGOs are not more likely for individuals of balanced upper class origin, than for those with cultural and economic upper class origin, in comparison to unskilled working class. Even though an educational credential is no prerequisite for attaining a political elite position, several contributions point to an increasing importance of educational degrees (e.g. Bovens and Wille 2009), which may explain the high estimate for the cultural upper class origin. For politicians and NGO-leaders, the associations with parental class are generally small in comparison to the other upper class subfractions. This is consistent with existing research suggesting that politics is among the most open elites in Norway (Hjellbrekke et al. 2007, Klausen 2002). 
The strongest tendency for closure is detected in the relative likelihood of becoming self-employed/proprietor/rentier. The odds of women originating in the economic upper class becoming an SPR are 42 times higher than women from the unskilled working class. Here, gender differences are striking; the corresponding figure for men is 13. Indeed, for each upperclass origin, the relative association between origin and becoming an SPR is significantly and substantively larger for women in comparison to men. This indicates that the women who do make it into these positions are very strongly selected in terms of social class.

Figure 4 visualizes capital-specific closure in each of these subdivisions. The first row shows the logit relationship for accessing each of the three subfractions of the cultural upper class, from each upper class origin, for men and women. As before, the reference category refers to men and women from unskilled working class origins. The second row depicts this relationship for the subfractions of the balanced upper class fraction, while the final row visualizes closure within the economic fraction. Within the cultural fraction, the confidence intervals indicate statistical significant levels of capital-specific closure for both men and women in academia, while only for men in the arts. Within the balanced subdivisions the only significant indication of strictly capital-specific closure is detected for men in the professions, as women from the balanced upper class fraction are not significantly more likely to enter the professions than women from the cultural upper class (yet distinctively more so than women from the economic upper class). This probably reflects the fact that the professions also depend significantly on cultural capital, which would make these positions more accessible for those with inherited cultural capital. In the economic upper class, significant closure is visible for men in all subdivisions, while only female SPRs and executives are significantly associated with economic upper class origins in comparison to the relative estimation for women from cultural or balanced upper class origins. 
In Figure 5, we present predicted probabilities for accessing each upper class fraction for men and women originating in the different fractions of the upper class. Although class origins appear more important for women than for men, the predicted probabilities for accessing each upper class fraction testify to the male dominance of these groups: overall, men enjoy significantly larger probabilities for entering the upper class, regardless of class origins. Within the balanced and economic fraction men have significantly and substantively larger probabilities of accessing power than women. It is, in fact, only in recruitment to the cultural upper class that gender differences seem insignificant. This is especially glaring in the economic upper class, whose sons enjoy dramatically higher chances of joining its ranks than its daughters.

\section{Conclusion}

Our analysis documents a considerable degree of upper class reproduction, relatively stable in the period studied, in line with our first expectation. Being born to upper-class parents yield superior chances of becoming upper class one self. In addition to the direct class reproduction, we find a differentiation of the chances of entering the upper class by two dimensions, in relation to both the volume and composition of parents' capital. The chances increase the further up in the class system one was born and the overall more capital the family held, as our second expectation postulated. Our third expectation concerned limitations on horizontal mobility, which was supported by our finding that the form of capital also differentiates the patterns of intergenerational closure. The relative chances are higher for obtaining a place in the cultural fraction of the upper class if one's parents' capital was predominantly cultural, either in the upper or lower middle class. The same principle applies to the other fractions: chances of joining the economic upper class are higher for those originating in one of the class fractions relatively richest in economic capital. In short, in addition to the direct self-recruitment of 
distinct classes, we see a pronounced tendency for what one might call capital-specific mobility barriers.

How do these tendencies of intergenerational social closure come about? It remains true that the market relationships at the heart of class divisions are open relationships - so that access to positions is in principle open to everyone (Weber 1978:43-8) - but the unequal distribution of capital entails unequal possibilities. Capital is, as Bourdieu noted, 'a force inscribed in the objectivity of things so that everything is not equally possible or impossible' (Bourdieu 1986:46). Economic capital can be directly inherited, it can pay for a house in catchment areas of 'better' schools, it can pay for a particularly exclusive higher education, or it can more indirectly function as a 'cushion' or 'insurance' against the risks involved in ambitious career choices. Those born into wealthy families are more likely than others to have access to family wealth helping them start up a business, as well as knowledge about investments strategies. Cultural capital makes schooling and education easier, helping to improve grades and the feeling of being 'at home' in the school system. So even if class positions need to be 'achieved' and cannot simply be 'ascribed' the distribution of capital involves a highly differential facilitation of and constraint on that achievement.

However, capital is also a force inscribed in the subjective structures of the habitus, according to Bourdieu. When comparing rates of joining the upper class by social class origin, we may, in a sense, be assessing the outcomes of a 'competition' that not everyone signed up for. But this can only explain the observed patterns if there is a systematic class difference in the pursuit of upper-class positions. This would be the case if people are socialised into specific classes and class fractions, and acquire knowledge and preferences guiding them towards careers within these classes. This is to say, children might develop a taste for the kind of jobs or careers that would position them within the same or a similar class position as their parents, and this might represent a form of what England (2016) has referred to as 'indirect constraint'. 
Those born in the middle classes are more likely to reach higher echelons of the class structure than the children of workers. Similarly, those born into the cultural middle classes more likely to enter class fractions rich in cultural than economic capital, and vice versa for those born into fractions richest in economic capital.

Our fourth expectation was to find tendencies towards closure to vary by the extent of credentialization. Our detailed analyses of different upper-class subfractions found no neat relationship between credentialization and closure in the upper class. The results unearthed a complex pattern that calls for more detailed and nuanced explanations than the extent of credentialization alone. Within the upper class fraction richest in cultural capital, for example, the subfractions theorized to be most and least depending on credentials - academics and artists, respectively - are marked by more closure than the 'middle' category of leaders.

Within the balanced fraction, it seems that credentialization implies stronger closure, and property plays a lesser role: the strongly credentialized professions are more closed than the less credentialized leaders, and the non-credentialized group of politicians and NGO-leaders are the most open to those originating in the lower reaches of social space. Within the economic fraction, the role of property seems very pronounced, as the uncredentialized and informal positions related to the self-employed, proprietors and rentiers exhibit the strongest tendency towards class reproduction. This tendency is less marked for the credentialized business professionals. The executives, who we classify as having a medium level of credentialization is the subfraction of the economic capital fraction that is least marked by class reproduction.

Bourdieu expected the composition of capital to constitute an important axis of class differentiation in most advanced capitalist societies. He found capital-specific forms of closure, similar to our findings, using material from 1970 (Bourdieu 1984:121). Savage and colleagues recalculated figures from Goldthorpe to show similar types of capital-specific mobility closure at work within the 'service class' in the UK (Savage et al. 1992:137-8), at least in 1970s. 
Although it cannot simply be assumed that this applies equally to all advanced capitalist societies, our analysis demonstrates the significance of both capital volume and composition and the differentiation of mobility chances around it. It is evident that these patterns would have been partly underestimated and partly undetected with a conventional measure of social class, such as the Goldthorpe scheme or its officially sanctioned offshoots. Its top category, 'service class', lumps together a series of positions that are very different in terms of both the volume of capital - in that they it does not distinguish between the upper class and the upper middle and the composition of capital (Flemmen 2014).

Finally, our results testify to the importance of accounting for closure in terms of the interplay of credentials and private property. Property is traditionally a blind spot for the sociology of stratification, which, owing to its close connection to the theory of industrial society, expected level of education to be both a vehicle of mobility, and the prime determinant of status attainment. Our analysis joins the vast literature that documents how education is in fact a key factor in class reproduction. Second, the results suggest that the widespread neglect of property in the sociology of inequality is indeed a shortcoming. There are no signs of a 'logic of industrialization' eliminating the role of private property in upper class reproduction. The power of private property and its correlate economic capital is of enduring significance for social mobility and closure. 


\section{Acknowledgments}

We would like to thank the participants at the Changing elites in Europe conference at the London School of Economics in 2015, where an earlier version of this paper was presented. We also want to thank Sociology's anonymous referees for very helpful comments and suggestions.

\section{Funding}

Parts of this research was funded by the Research Council of Norway, grant no 


\section{References}

Aberbach JD, Putnam RD and Rockman BA (1981) Bureaucrats and politicians in western democracies. Cambridge, Mass: Harvard University Press.

Andersen PL. (2014) Den norske politiske eliten. Sammenhengen mellom politiske posisjoner, klassebakgrunn og utdanning. In: Korsnes O, Hansen MN and Hjellbrekke J (eds) Elite og klasse $i$ et egalitcert samfunn. Oslo: Universitetsforlaget.

Andersen PL and Hansen MN. (2011) Class and Cultural Capital-The Case of Class Inequality in Educational Performance. European Sociological Review 28: 1-15.

Atkinson AB. and Morelli S (2014) Chartbook of Economic Inequality. ECINEQ WP 324. Retrieved June 1, 2015 (http://papers.ssrn.com/sol3/papers.cfm?abstract_id=2422269).

Blanchflower DG. and Oswald AJ (1998) What Makes an Entrepreneur?, Journal of Labor Economics 16 (1):26-60. doi: doi:10.1086/209881.

Bourdieu P (1984) Distinction: A Social Critique of the Judgement of Taste. London: Routledge.

Bourdieu P (1986) The Forms of Capital. In: Handbook for Theory and Research for the Sociology of Education, edited by J.G. Richardson. New York: Greenwood.

Bourdieu, P (1996) The State Nobility. Cambridge: Polity Press.

Bourdieu P (2005) The social structures of the economy. Cambridge: Polity.

Bovens M and Wille A (2009) Diploma democracy. On the Tensions between Meritocracy and Democracy. In Research NOfS (Ed.) Verkenning for the NWO programme Contested Democracies. Utrecht/ Leiden.

Breen R (2005) Foundations of a neo-Weberian Class Analysis. In: Wright EO (ed.) Approaches to Class Analysis. Cambridge: Cambridge University Press.

England P (2016) Sometimes the Social Becomes Personal: Gender, Class, and Sexualities. American Sociological Review 81(1): 4-28.

Erikson R and Goldthorpe JH (1993) The Constant Flux. A Study of Class Mobility in Industrial Societies. Oxford: Clarendon Press.

Flemmen M (2009) Den økonomiske overklassens sosiale lukning. Tidsskrift for samfunnsforskning 50: 493-522.

Flemmen M (2012) The Structure of the Upper Class: A Social Space Approach. Sociology 46: 1039-1058.

Flemmen M (2013) Putting Bourdieu to work for class analysis: Reflections on some recent contributions. British Journal of Sociology 64: 325-343.

Flemmen M (2014) The Politics of the Service Class: The homology of positions and positiontakings. European Societies 16: 543-569.

Flemmen M Jarness V and Rosenlund L (forthcoming) Social Space and Cultural Class Divisions: The Forms of Capital and Contemporary Lifestyle Differentiation. British Journal of Sociology.

Friedman S, O'Brien D and Laurison D (2016) 'Like Skydiving without a Parachute': How Class Origin Shapes Occupational Trajectories in British Acting. Sociology.

Goldthorpe JH (1982) On the service class, its formation and future. In: Giddens A and Mackenzie G (eds) Social class and the division of labour. London: Cambridge University Press.

Goldthorpe JH, Llewellyn C and Payne C (1987) Social mobility and class structure in modern Britain. Clarendon Press, (http://books.google.no/books?id=ZG3qPsldoyIC).

Gulbrandsen T, Engelstad F, Klausen TB, Skjeie H, Teigen M and Østerud Ø (2002) Norske makteliter, Makt- og demokratiutredningen. Oslo: Gyldendal. 
Hansen MN. (2001) Closure in an Open Profession. The Impact of Social Origin on the Educational and Occupational Success of Graduates of Law in Norway. Work, Employment \& Society 15: 489-510.

Hansen MN. (2005) Den sosiale rekrutteringen til medisinstudiet. Tidsskrift for Den norske legeforening 125: 2213-2215.

Hartmann M (2010) Elites and Power Structure. In: Immerfall S and Therborn G (eds) Handbook of European Societies. Springer New York, 291-323.

Higley J, Field GL and Grøholt K (1976) Elite structure and ideology: a theory with applications to Norway. Oslo: Universitetsforlaget.

Hjellbrekke J and Korsnes O (2010) Nedturar. Deklassering i det seinmoderne Noreg. Nytt Norsk Tidsskrift 27(1-2): 46-59.

Hjellbrekke J, Le Roux B, Korsnes O, Lebaron F, Rosenlund L and Rouanet H (2007) The Norwegian field of power anno 2000. European Societies 9(2).

Khan SR (2012) The Sociology of Elites. Annual Review of Sociology 38(1): 361-77.

Klausen TB (2002) En lukket elite? In: Gulbrandsen T (ed.) Norske makteliter, [A closed elite?]. Oslo: Gyldendal Norsk Forlag AS, 75 - 92.

Lareau A (2003) Unequal childhoods: class, race, and family life. Berkeley: University of California Press.

Ljunggren J (2010) En norsk kulturelite? En studie av gruppedannelse gjennom bosted, sosial bakgrunn og partnervalg. Institutt for sosiologi og samfunnsgeografi. Oslo: Universitetet i Oslo.

Ljunggren J (2015) Elitist Egalitarianism: Negotiating Identity in the Norwegian Cultural Elite. Sociology. doi:10.1177/0038038515590755

Ljunggren $\mathbf{J}$ (2016) Economic rewards in the cultural upper class: The impact of social origin on income within the Norwegian field of culture. Poetics 57: 14-26.

Marx K (1976) Capital Volume I. London: Penguin Books.

Mastekaasa A (2004) Social Origins and Recruitment to Norwegian Business and Public Sector Elites. European Sociological Review 20(3): 221-35.

Murphy R (1988) Social closure: the theory of monopolization and exclusion. Oxford: Clarendon Press.

Norris P and Lovenduski J (1995) Political recruitment: gender, race and class in the British parliament. Cambridge: Cambridge University Press.

Page EC and Wright V (1999) Bureaucratic élites in Western European states. Oxford: Oxford Univiversity Press.

Parkin F (1979) Marxism and class theory: a bourgeois critique. New York: Columbia University Press.

Pfeffer F and Hällsten M (2012) Mobility Regimes and Parental Wealth: The United States, Germany, and Sweden in Comparison. PSC Research Report.

Piketty T (2014) Capital in the twenty-first century. Cambridge, Mass.: Belknap Press.

Rose D and Harrison E (2010) Social class in Europe : an introduction to the European socioeconomic classification, Routledge/ESA studies in European societies. London: Routledge.

Rose D and Pevalin DJ (2003) A researcher's guide to the national statistics socio-economic classification. SAGE Publications Ltd.

Savage M (2015) Introduction to elites From the 'problematic of the proletariat' to a class analysis of 'wealth elites'. The Sociological Review 63(2): 223-39.

Savage M, Cunningham N, Devine F, Friedman S, Laurison D, Mckenzie L, Miles A, Snee H and Wakeling P (2015) Social Class in the 21 st Century. London: Penguin. 
Savage M, Devine F, Cunningham N, Taylor M, Li Y, Hjellbrekke J, Le Roux B, Friedman S and Miles A (2013) A New Model of Social Class? Findings from the BBC's Great British Class Survey Experiment. Sociology 47(2): 219-50.

Savage M and Williams K (eds.) (2008) Remembering Elites, Malden, Mass: Blackwell.

Scott J (1997) Corporate Business and Capitalist Classes. Oxford: Oxford University Press.

Strømme T B \& Hansen M N (2017) Closure in the elite professions: the field of law and medicine in an egalitarian context. Journal of Education and Work 30(2): 168-85.

Toft $\mathrm{M}$ and Flemmen $\mathrm{M}$ (forthcoming) The gendered reproduction of the upper class. In: Korsnes O, Heilbron J, Hjellbrekke J, Bühlmann F and Savage M (eds) New Directions in Elite Research. London: Routledge.

Weber M (1978) Economy and society: an outline of interpretive sociology. Berkeley, Calif.: University of California Press.

Wright EO (2005) Foundations of a neo-Marxist Class Analysis. In: Wright EO (ed.) Approaches to Class Analysis. Cambridge: Cambridge University Press. 
Author 1:

Name: Magne Paalgard Flemmen

Institution: Department of Sociology and Human Geography, University of Oslo

Biography: Magne Flemmen is post-doctoral research fellow in sociology at the University of Oslo. His research interests lie in the areas of class analysis, class theory, social stratification and inequality more broadly. His recent work focuses on the theory and model of social space, as well as cultural and political components of class divisions.

Author 2:

Name: Maren Toft

Institution: Department of Sociology and Human Geography, University of Oslo

Biography : Maren Toft is a PhD candidate in sociology at the Department of sociology and human geography at the University of Oslo. Her research areas include a general interest in class divisions with particular emphasis on class trajectories, urban inequality and temporality.

Author 3:

Name: Patrick Lie Andersen

Institution: Norwegian Social Research (NOVA

Biography: Patrick Lie Andersen is a researcher at NOVA, Centre for Welfare and Labour Research, Oslo and Akershus University College of Applied Sciences, and a PhD student in sociology at the University of Oslo. His research concerns social inequality, with a particular focus on social classes and living conditions among adolescents.

Author 4:

Name: Marianne Nordli Hansen

Institution: Department of sociology and human geography, University of Oslo 
Biography: Marianne Nordli Hansen is Professor at the Department of Sociology and Human Geography at the University of Oslo. Her academic interests are in the fields of social stratification, social class, education, economic inequalities, and elites. Her publications include work on recruitment to higher education, cultural capital, income mobility and wealth mobility. At present, she is working on a project about elites.

\section{Author 5:}

Name: Jørn Ljunggren

Institution:

Biography: Jørn Ljunggren is a Senior Research Fellow at Institute for Social Research, Norway. His primary academic interests concern social stratification, urban inequality, social class and in particular the intersections of economic and cultural capital. He is currently working on projects concerning ethnic and gendered patterns in elite recruitment. 
Figure 1: The ORDC class scheme with examples of occupations

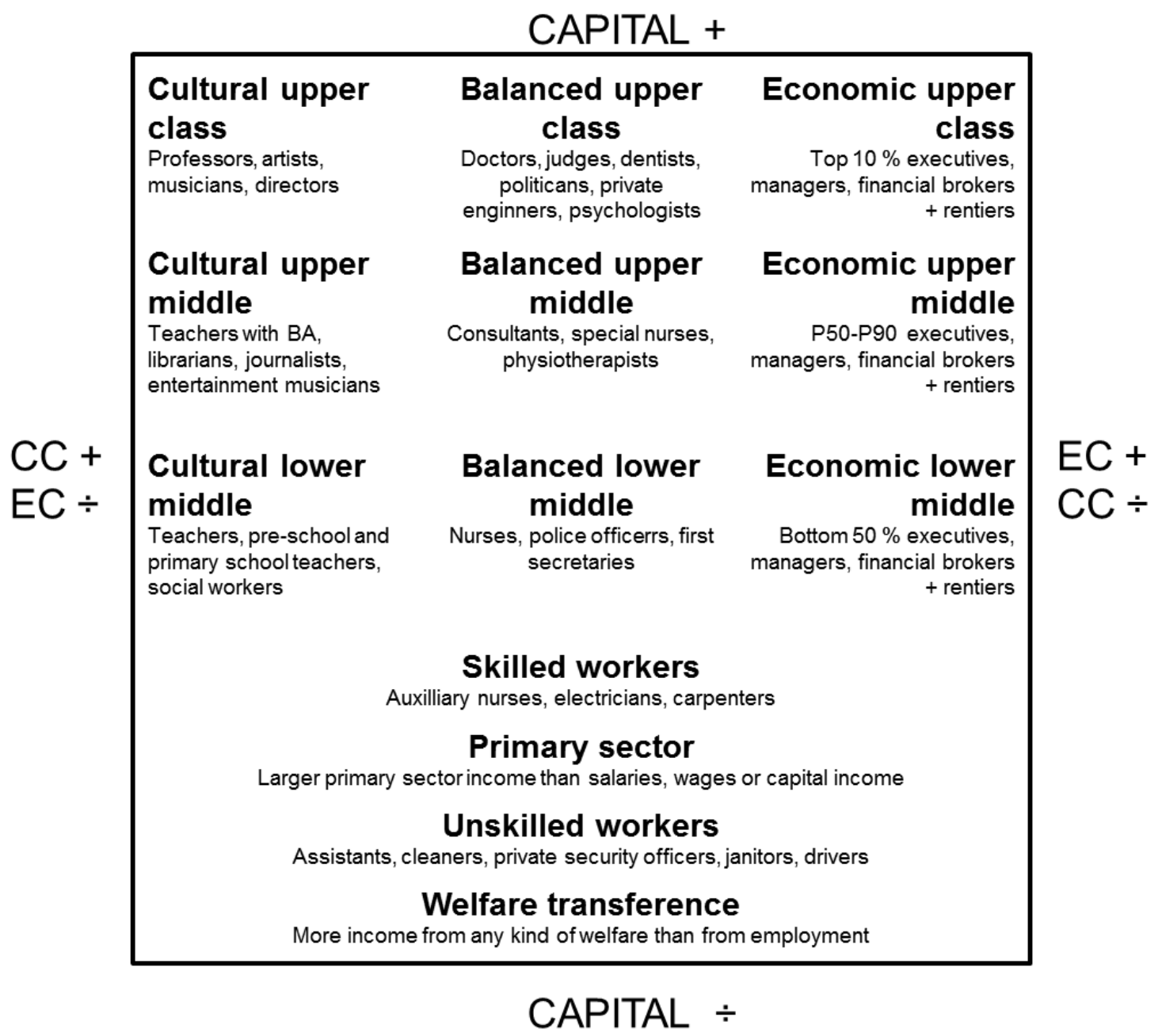


Figure 2: Divisions of upper class fractions into subfractions by degree of credentialization. + indicates high degree of credentialization, - indicates low degree and no symbol indicates medium credentialization.

\section{Upper Classes}

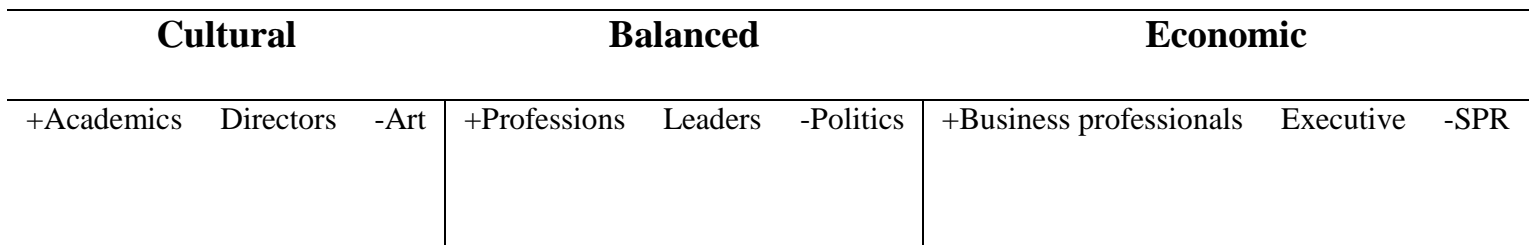


Table 1: Descriptive statistics

\begin{tabular}{|c|c|}
\hline \multicolumn{2}{|l|}{ Upper class fractions, per cent } \\
\hline Culture & 1.16 \\
\hline Balanced & 2.36 \\
\hline Economic & 2.12 \\
\hline Other/lower & 94.35 \\
\hline Total & 100.00 \\
\hline \multicolumn{2}{|l|}{ Upper class subdivision, per cent } \\
\hline \multicolumn{2}{|l|}{ Culture } \\
\hline Academic & 0.84 \\
\hline Director & 0.10 \\
\hline Art & 0.21 \\
\hline \multicolumn{2}{|l|}{ Balanced } \\
\hline Profession & 1.84 \\
\hline Leader & 0.39 \\
\hline Politics/NGO & 0.12 \\
\hline \multicolumn{2}{|l|}{ Economic } \\
\hline Business professionals & 0.37 \\
\hline Executive & 1.30 \\
\hline SPR & 0.45 \\
\hline Other/lower & 94.35 \\
\hline Total & 100.00 \\
\hline \multicolumn{2}{|l|}{ Parental class, per cent } \\
\hline Upper class: culture & 1.10 \\
\hline upper class: balanced & 4.08 \\
\hline upper class: economic & 1.36 \\
\hline Upper middle class: culture & 2.40 \\
\hline Upper middle class: balanced & 6.09 \\
\hline Upper middle class: economic & 7.11 \\
\hline Lower middle class: culture & 2.26 \\
\hline Lower middle class: balanced & 9.86 \\
\hline Lower middle class: economic & 4.90 \\
\hline Skilled working class & 20.04 \\
\hline Unskilled working class & 34.95 \\
\hline Farmers, fishery & 5.84 \\
\hline Total & 100.00 \\
\hline \multicolumn{2}{|l|}{ Gender, per cent } \\
\hline Men & 51.30 \\
\hline Women & 48.70 \\
\hline Total & 100.00 \\
\hline Observations & 609,499 \\
\hline
\end{tabular}


Table 2: Logit coefficients from multinomial regression analyses estimating the relationship between parental class and adult class position conditioning on gender. Control for time period. (Base category $=$ no upper class position)

\begin{tabular}{|c|c|c|c|c|c|c|}
\hline & \multirow{2}{*}{$\begin{array}{c}\text { (Upper class) } \\
\text { Culture } \\
\end{array}$} & \multirow[b]{2}{*}{ S.E. } & \multirow{2}{*}{$\begin{array}{c}\text { (Upper class) } \\
\text { Balanced }\end{array}$} & \multicolumn{3}{|c|}{ (Upper class) } \\
\hline & & & & S.E. & Economic & S.E. \\
\hline Unskilled working class & ref. & & ref. & & ref. & \\
\hline Upper class: culture & $2.93 * * *$ & $(0.08)$ & $1.89 * * *$ & $(0.07)$ & $1.50 * * *$ & $(0.08)$ \\
\hline Upper class: balanced & $2.17 * * *$ & $(0.06)$ & $2.13 * * *$ & $(0.04)$ & $1.80 * * *$ & $(0.04)$ \\
\hline Upper class: economic & $1.89 * * *$ & $(0.10)$ & $1.58 * * *$ & $(0.07)$ & $2.62 * * *$ & $(0.05)$ \\
\hline Upper middle class: culture & $2.34 * * *$ & $(0.07)$ & $1.74 * * *$ & $(0.05)$ & $1.39 * * *$ & $(0.05)$ \\
\hline Upper middle class: balanced & $1.40 * * *$ & $(0.07)$ & $1.25 * * *$ & $(0.04)$ & $1.01 * * *$ & $(0.04)$ \\
\hline Upper middle class: economic & $1.45 * * *$ & $(0.06)$ & $1.24 * * *$ & $(0.04)$ & $1.75 * * *$ & $(0.03)$ \\
\hline Lower middle class: culture & $1.76 * * *$ & $(0.08)$ & $1.28 * * *$ & $(0.06)$ & $0.98 * * *$ & $(0.06)$ \\
\hline Lower middle class: balanced & $0.73 * * *$ & $(0.07)$ & $0.69 * * *$ & $(0.04)$ & $0.64 * * *$ & $(0.04)$ \\
\hline Lower middle class: economic & $0.98 * * *$ & $(0.08)$ & $0.75 * * *$ & $(0.05)$ & $1.10 * * *$ & $(0.04)$ \\
\hline Skilled working class & $0.49 * * *$ & $(0.06)$ & $0.45^{* * *}$ & $(0.04)$ & $0.54 * * *$ & $(0.03)$ \\
\hline Farmers, forestry & $0.22 *$ & $(0.10)$ & $0.16^{* *}$ & $(0.06)$ & $0.28 * * *$ & $(0.06)$ \\
\hline Women & 0.18 & $(0.12)$ & $0.43 * * *$ & $(0.11)$ & $0.63 * * *$ & $(0.18)$ \\
\hline Upper class: culture \# women & $0.28 * *$ & $(0.10)$ & $0.32 * * *$ & $(0.07)$ & $0.36 * *$ & $(0.11)$ \\
\hline Upper class: balanced \# women & $0.36^{*}$ & $(0.15)$ & $0.56^{* * *}$ & $(0.11)$ & $0.40 * * *$ & $(0.12)$ \\
\hline Upper class: economic \# women & 0.09 & $(0.11)$ & $0.34 * * *$ & $(0.09)$ & 0.25 & $(0.15)$ \\
\hline Upper middle class: culture \# women & 0.05 & $(0.11)$ & 0.11 & $(0.08)$ & $0.37 * *$ & $(0.12)$ \\
\hline Upper middle class: balanced \# women & 0.19 & $(0.10)$ & $0.34 * * *$ & $(0.07)$ & $0.32 * * *$ & $(0.10)$ \\
\hline Upper middle class: economic \# women & $0.30 *$ & $(0.13)$ & 0.19 & $(0.11)$ & 0.27 & $(0.18)$ \\
\hline Lower middle class: culture \# women & $0.33^{* *}$ & $(0.11)$ & 0.07 & $(0.08)$ & 0.22 & $(0.12)$ \\
\hline Lower middle class: balanced \# women & 0.13 & $(0.13)$ & $0.20 *$ & $(0.10)$ & 0.23 & $(0.13)$ \\
\hline Lower middle class: economic \# women & $0.23 *$ & $(0.10)$ & -0.00 & $(0.07)$ & 0.12 & $(0.10)$ \\
\hline Skilled Working class \# women & $0.34 *$ & $(0.15)$ & $0.29 * *$ & $(0.11)$ & $0.42 * *$ & $(0.15)$ \\
\hline Farmers, forestry \# women & $2.93 * * *$ & $(0.08)$ & $1.89 * * *$ & $(0.07)$ & $1.50 * * *$ & $(0.08)$ \\
\hline 2003 & ref. & & ref. & & ref. & \\
\hline 2004 & -0.06 & $(0.05)$ & 0.02 & $(0.04)$ & 0.03 & $(0.04)$ \\
\hline 2005 & $-0.11 *$ & $(0.06)$ & 0.02 & $(0.04)$ & 0.03 & $(0.04)$ \\
\hline 2006 & $-0.14 *$ & $(0.06)$ & $0.12 * *$ & $(0.04)$ & $0.12 * *$ & $(0.04)$ \\
\hline 2007 & -0.10 & $(0.05)$ & $0.09 *$ & $(0.04)$ & $0.11^{*}$ & $(0.04)$ \\
\hline 2008 & $-0.12 *$ & $(0.05)$ & $0.19 * * *$ & $(0.04)$ & $0.19 * * *$ & $(0.04)$ \\
\hline 2009 & -0.09 & $(0.05)$ & $0.21 * * *$ & $(0.04)$ & $0.16 * * *$ & $(0.04)$ \\
\hline 2010 & -0.07 & $(0.05)$ & $0.15^{* * *}$ & $(0.04)$ & $0.16^{* * * *}$ & $(0.04)$ \\
\hline 2011 & $-0.12 *$ & $(0.05)$ & $0.17 * * *$ & $(0.04)$ & $0.16^{* * *}$ & $(0.04)$ \\
\hline 2012 & -0.09 & $(0.05)$ & $0.21 * * *$ & $(0.04)$ & $0.12 * *$ & $(0.04)$ \\
\hline Constant & $-5.08 * * *$ & $(0.054)$ & $-4.21 * * *$ & $(0.037)$ & $-4.14 * * *$ & $(0.038)$ \\
\hline Observations & 609,499 & & 609,499 & & 609,499 & \\
\hline
\end{tabular}

Note: Standard errors in parentheses. $* * * \mathrm{p}<0.001, * * \mathrm{p}<0.01, * \mathrm{p}<0.05$ 
Figure 3: Logit coefficients with $95 \%$ confidence intervals for men and women with origins from the three upper class fractions in comparison to men and women with origins in the unskilled working class. The outcome variable measures position in either i) the cultural fraction of the upper class, ii) the balanced fraction of the upper class, iii) the economic fraction of the upper class, controlling for time period.
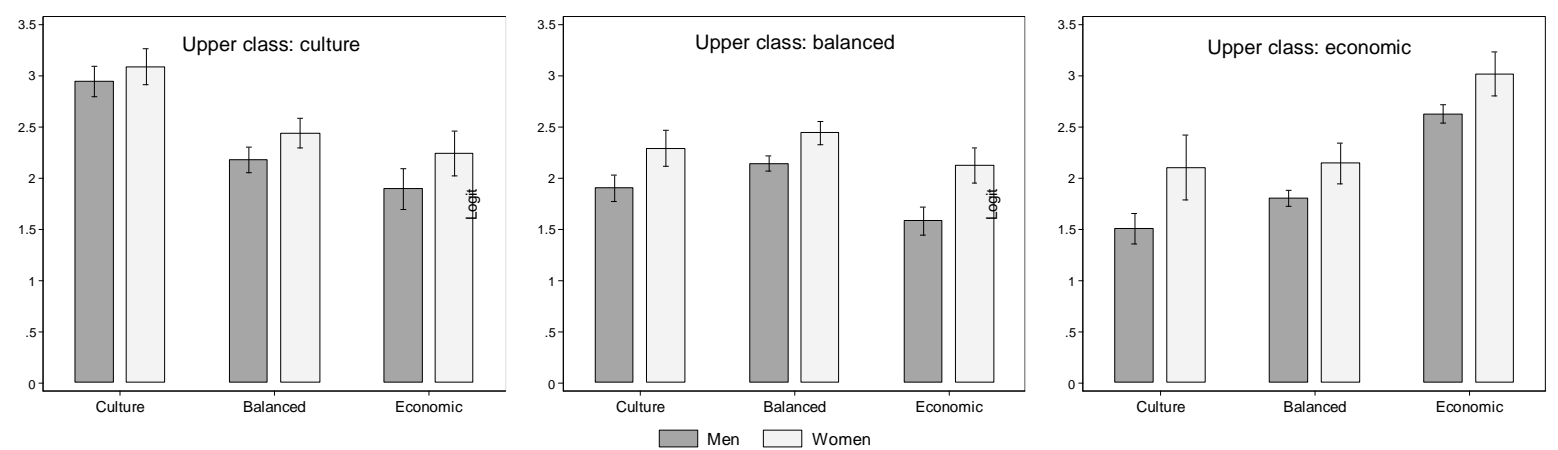
Table 3: Logit coefficients from multinomial regression analyses estimating the relationship between parental class and adult class position controlling for year and conditioning on gender. (Base category $=$ no upper class position)

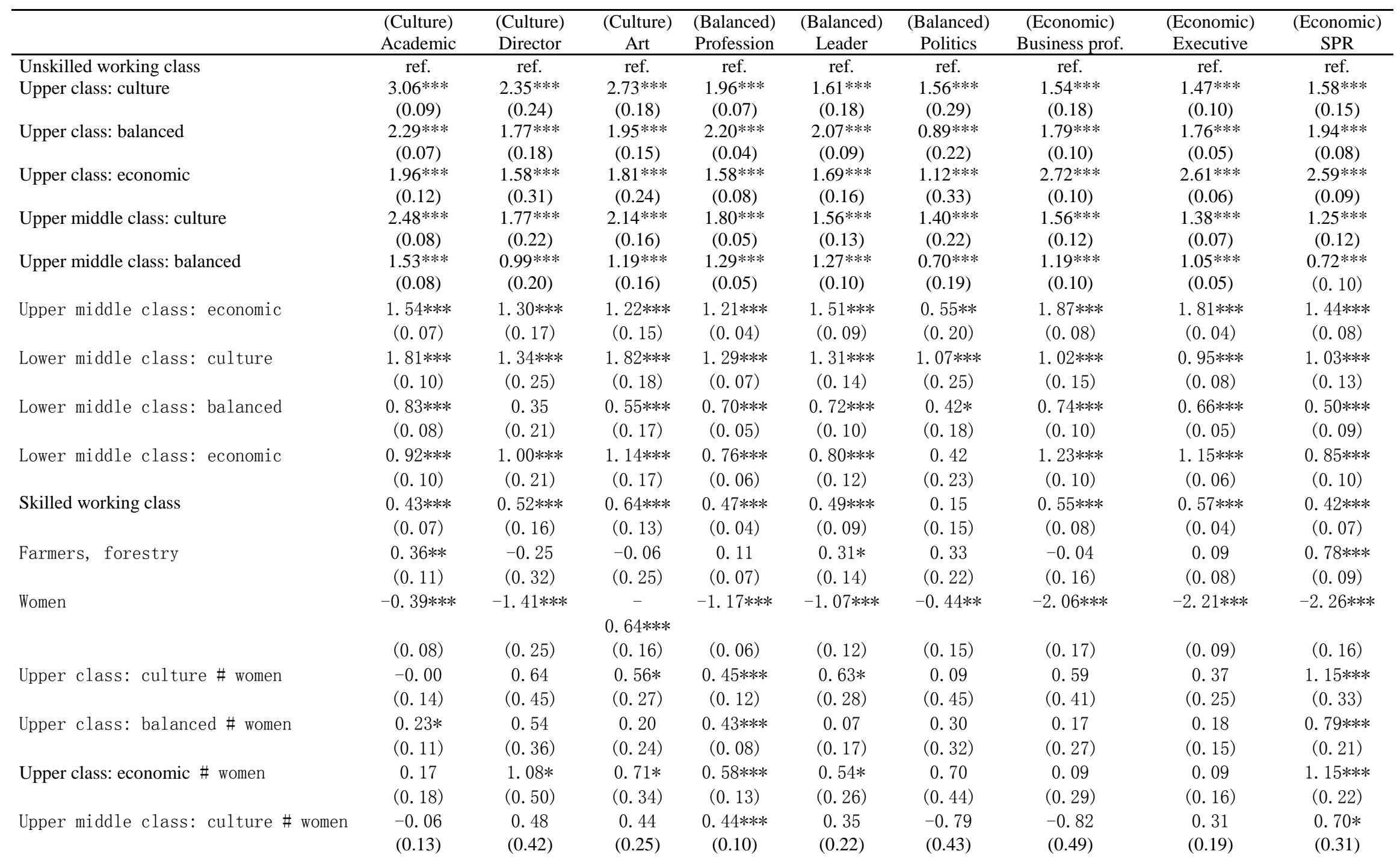




\begin{tabular}{|c|c|c|c|c|c|c|c|c|c|}
\hline Upper middle class: balanced \# women & $\begin{array}{l}-0.09 \\
(0.12)\end{array}$ & $\begin{array}{l}0.43 \\
(0.40)\end{array}$ & $\begin{array}{c}0.36 \\
(0.25)\end{array}$ & $\begin{array}{l}0.20^{*} \\
(0.09)\end{array}$ & $\begin{array}{c}0.01 \\
(0.19)\end{array}$ & $\begin{array}{l}-0.39 \\
(0.34)\end{array}$ & $\begin{array}{l}-0.01 \\
(0.29)\end{array}$ & $\begin{array}{c}0.21 \\
(0.16)\end{array}$ & $\begin{array}{c}1.09 * * * \\
(0.24)\end{array}$ \\
\hline \multirow[t]{2}{*}{ Upper middle class: economic \# women } & 0.03 & 0.52 & $0.64 * *$ & $0.42 * * *$ & 0.21 & 0.29 & 0.21 & 0.13 & $0.93 * * *$ \\
\hline & $(0.12)$ & $(0.35)$ & $(0.23)$ & $(0.08)$ & $(0.17)$ & $(0.29)$ & $(0.22)$ & $(0.13)$ & $(0.20)$ \\
\hline \multirow[t]{2}{*}{ Lower middle class: culture \# women } & 0.17 & 0.65 & 0.53 & $0.29 *$ & 0.14 & -0.57 & 0.43 & 0.22 & 0.25 \\
\hline & $(0.15)$ & $(0.48)$ & $(0.27)$ & $(0.12)$ & $(0.26)$ & $(0.47)$ & $(0.39)$ & $(0.23)$ & $(0.39)$ \\
\hline \multirow[t]{2}{*}{ Lower middle class: balanced \# women } & 0.22 & 0.75 & 0.50 & 0.10 & 0.09 & -0.03 & 0.30 & 0.07 & $0.51 *$ \\
\hline & $(0.12)$ & $(0.39)$ & $(0.26)$ & $(0.09)$ & $(0.19)$ & $(0.28)$ & $(0.26)$ & $(0.16)$ & $(0.25)$ \\
\hline \multirow[t]{2}{*}{ Lower middle class: economic \# women } & 0.13 & 0.29 & 0.12 & 0.20 & 0.29 & 0.22 & -0.04 & 0.15 & $0.68^{*}$ \\
\hline & $(0.15)$ & $(0.44)$ & $(0.28)$ & $(0.11)$ & $(0.22)$ & $(0.35)$ & $(0.31)$ & $(0.16)$ & $(0.27)$ \\
\hline \multirow[t]{2}{*}{ Skilled working class \# women } & $0.28^{*}$ & 0.22 & 0.07 & 0.04 & -0.32 & 0.28 & 0.28 & -0.12 & $0.55^{* *}$ \\
\hline & $(0.11)$ & $(0.34)$ & $(0.22)$ & $(0.08)$ & $(0.18)$ & $(0.23)$ & $(0.23)$ & $(0.14)$ & $(0.21)$ \\
\hline \multirow[t]{2}{*}{ Farmers, forestry \#women } & 0.20 & $1.26^{*}$ & 0.44 & 0.26 & 0.40 & 0.17 & $1.19 * * *$ & 0.09 & 0.41 \\
\hline & $(0.17)$ & $(0.51)$ & (0.39) & $(0.13)$ & $(0.25)$ & $(0.34)$ & $(0.32)$ & $(0.24)$ & $(0.28)$ \\
\hline 2003 & ref. & ref. & ref. & ref. & ref. & ref. & ref. & ref. & ref. \\
\hline \multirow[t]{2}{*}{2004} & -0.07 & -0.08 & 0.01 & 0.01 & 0.09 & 0.02 & 0.18 & 0.08 & -0.13 \\
\hline & $(0.06)$ & $(0.17)$ & $(0.14)$ & $(0.05)$ & $(0.10)$ & $(0.16)$ & $(0.12)$ & $(0.06)$ & $(0.08)$ \\
\hline \multirow[t]{2}{*}{2005} & -0.11 & -0.30 & -0.01 & 0.04 & 0.00 & -0.16 & 0.21 & 0.03 & -0.06 \\
\hline & $(0.06)$ & $(0.19)$ & $(0.14)$ & $(0.05)$ & $(0.10)$ & $(0.16)$ & $(0.12)$ & $(0.06)$ & $(0.08)$ \\
\hline \multirow[t]{2}{*}{2006} & $-0.16^{*}$ & -0.22 & -0.00 & $0.13^{* *}$ & 0.17 & -0.17 & $0.48 * * *$ & $0.17 * *$ & $-0.17 *$ \\
\hline & $(0.06)$ & $(0.18)$ & $(0.14)$ & $(0.05)$ & $(0.10)$ & $(0.16)$ & $(0.11)$ & $(0.06)$ & $(0.08)$ \\
\hline \multirow[t]{2}{*}{2007} & $-0.12 *$ & -0.06 & -0.01 & $0.11 *$ & 0.14 & -0.30 & $0.59 * * *$ & $0.14^{*}$ & $-0.26^{* *}$ \\
\hline & $(0.06)$ & $(0.17)$ & $(0.14)$ & $(0.05)$ & $(0.10)$ & $(0.17)$ & $(0.11)$ & $(0.06)$ & $(0.08)$ \\
\hline \multirow[t]{2}{*}{2008} & $-0.13 *$ & -0.33 & 0.06 & $0.19 * * *$ & $0.26 * *$ & 0.14 & $0.49 * * *$ & $0.31 * * *$ & $-0.27 * * *$ \\
\hline & $(0.06)$ & $(0.19)$ & $(0.13)$ & $(0.05)$ & $(0.10)$ & $(0.15)$ & $(0.11)$ & $(0.05)$ & $(0.08)$ \\
\hline \multirow[t]{2}{*}{2009} & $-0.14 *$ & -0.07 & 0.12 & $0.23 * * *$ & $0.20 *$ & 0.07 & $0.53 * * *$ & $0.31 * * *$ & $-0.44 * * *$ \\
\hline & $(0.06)$ & $(0.17)$ & $(0.13)$ & $(0.04)$ & $(0.10)$ & $(0.15)$ & $(0.11)$ & $(0.05)$ & $(0.08)$ \\
\hline \multirow[t]{2}{*}{2010} & $-0.14^{*}$ & -0.07 & 0.21 & $0.15 * * *$ & $0.27 * *$ & -0.26 & $0.52 * * *$ & $0.32 * * *$ & $-0.51 * * *$ \\
\hline & $(0.06)$ & $(0.17)$ & $(0.13)$ & $(0.05)$ & $(0.10)$ & $(0.17)$ & $(0.11)$ & $(0.05)$ & $(0.09)$ \\
\hline \multirow{2}{*}{2011} & $-0.19 * *$ & -0.19 & 0.21 & $0.19 * * *$ & $0.23^{*}$ & -0.32 & $0.52 * * *$ & $0.33 * * *$ & $-0.51 * * *$ \\
\hline & $(0.06)$ & $(0.18)$ & $(0.13)$ & $(0.04)$ & $(0.10)$ & $(0.17)$ & $(0.11)$ & $(0.05)$ & $(0.09)$ \\
\hline \multirow[t]{2}{*}{2012} & $-0.18^{* *}$ & -0.12 & $0.29^{*}$ & $0.20 * * *$ & $0.36^{* * *}$ & -0.22 & $0.58 * * *$ & $0.28 * * *$ & $-0.67 * * *$ \\
\hline & $(0.06)$ & $(0.17)$ & $(0.12)$ & $(0.04)$ & (0.09) & $(0.16)$ & $(0.10)$ & $(0.05)$ & $(0.09)$ \\
\hline \multirow[t]{2}{*}{ Constant } & $-5.46 * * *$ & $-6.99 * * *$ & $-6.91 * * *$ & $-4.47 * * *$ & $-6.07 * * *$ & $-6.75^{* * *}$ & $-6.28 * * *$ & $-4.72 * * *$ & $-5.26 * * *$ \\
\hline & $(0.06)$ & $(0.16)$ & $(0.13)$ & $(0.04)$ & $(0.09)$ & $(0.14)$ & $(0.10)$ & $(0.05)$ & $(0.07)$ \\
\hline Observations & 609,499 & 609,499 & 609,499 & 609,499 & 609,499 & 609,499 & 609,499 & 609,499 & 609,499 \\
\hline
\end{tabular}


Figure 4: Logit coefficients with $95 \%$ confidence intervals for men and women with origins from the three upper class fractions in comparison to men and women with origins in the unskilled working class. The outcome variable measures position in each of the 9 subdivisions within the upper class, controlling for time period.
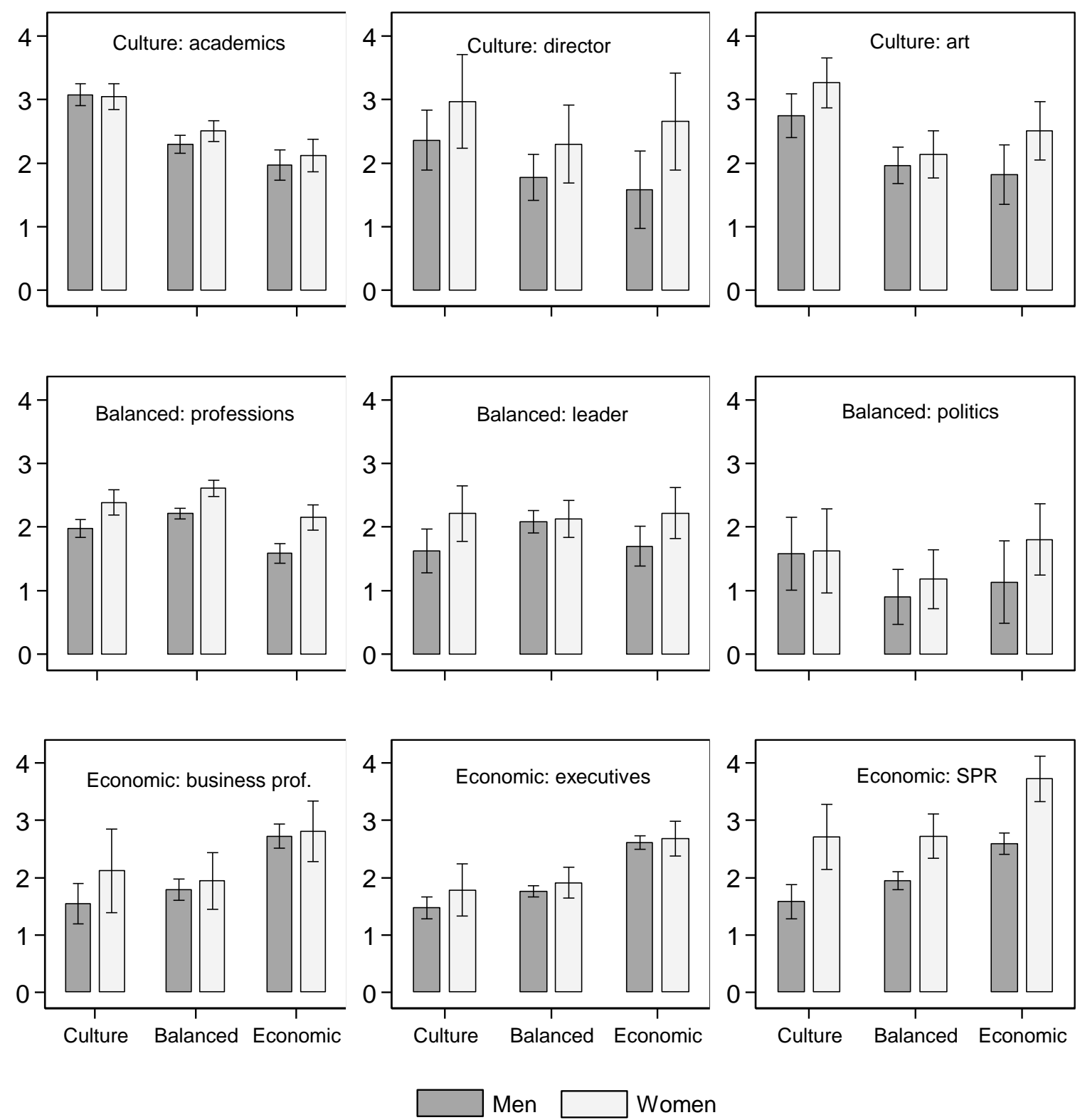
Figure 5: Predicted probabilities for accessing each upper class fraction for men and women from the three upper class fractions. 95\% CI.
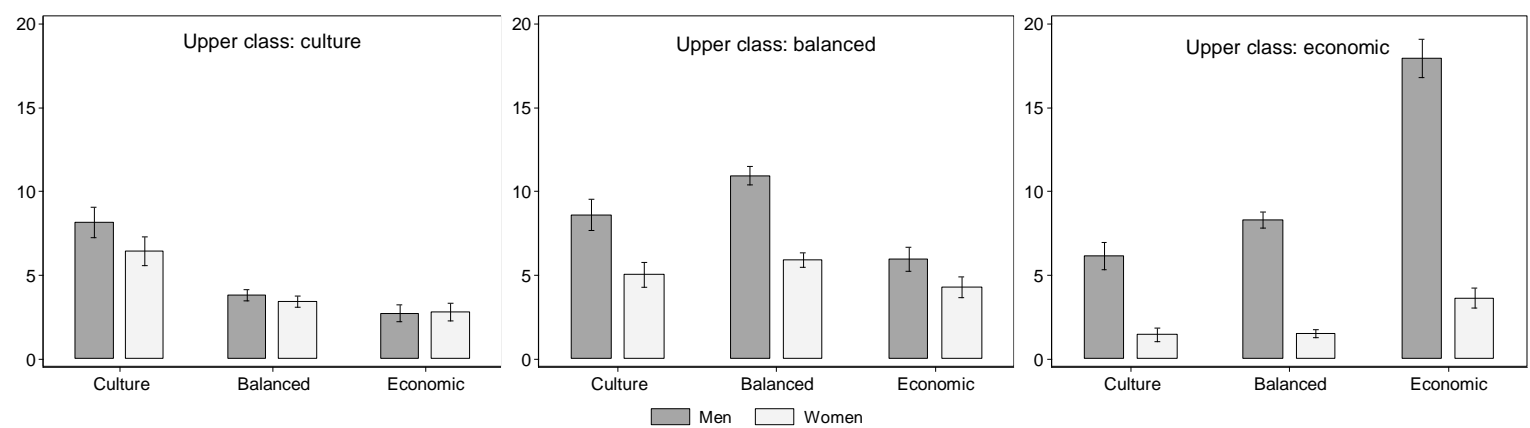